\title{
The Amazing Potential of Fungi in Human Life
}

\author{
Waill A. Elkhateeb *, Ghoson M. Daba \\ Chemistry of Natural and Microbial Products Department, Pharmaceutical Industries Researches Division, \\ National Research Centre, Egypt.
}

*Corresponding Author: Waill A. Elkhateeb, Chemistry of Natural and Microbial Products Department, Pharmaceutical Industries Researches Division, National Research Centre, Egypt.

\begin{abstract}
Fungi have provided the world with penicillin, lovastatin, and other globally significant medicines, and they remain an unexploited resource with huge industrial potential. Fungi are an understudied, biotechnologically valuable group of organisms, due to the huge range of habitats that fungi inhabit, fungi represent great promise for their application in biotechnology and industry. This review demonstrate that fungal mycelium as a medium, the vegetative part can potentially be utilized in plastic biodegradation and growing alternative and sustainable materials. Innovative fungal mycelium-based biofoam demonstrate that this biofoam offers great potential for application as an alternative insulation material for building and infrastructure construction.
\end{abstract}

Keywords: Degradation of plastic, plastic degrading fungi, bioremediation, grown materials, Ecovative, fungal mycelium-based biofoam

\section{INTRODUCTION}

Plastic is a naturally refractory polymer, once it enters the environment, it will remain there for many years. Accumulation of plastic as wastes in the environment poses a serious problem and causes an ecological threat. [1]. The rapid development of chemical industry in the last century has led to the production of approximately 140 million tons of various polymers annually [2]. Many of these are non- biodegradable and persist almost identify in an environment, their accumulation has triggered research to develop more readily degradable materials and identify new methods for eliminating existing polymer waste [3]. Biodegradation of polymers is seen as one of the solution for current plastic waste management problems. Microorganisms are capable of degrading most of the organic and inorganic materials. Plastic materials have gained widespread use as they have been increasingly used in food, clothing, shelter, transportation, construction, medical and leisure industries. Plastics are composed of petroleum based materials called resins (e.g., polythene, polypropylene and polyurethane) materials that are resistant to biodegradation. [4-6].

\section{MYCOREMEDIATION FOR A GREENER ENVIRONMENT}

Polyurethane (PU) not only has applications including tires and insulation, but also is an essential element of our lives. Based on previous reports, some strains of fungus including Pestalotiopsis microspora have been reported to degrade this plastic. The ultimate objective is to create a genetically engineered variant of Pichia pastoris which will digest polyester polyurethane (PUR) using the enzyme responsible for PUR degradation from Aspergillus flavus. Esterase, the enzyme responsible for the degradation of the water-based PUR [7]. Polyurethane (PU) biodegradation by microorganisms had become an important issue in the study of degradation mechanisms and PU aging. PU 
biodegradation could be due to utilization of this material as carbon or nitrogen source by the microorganisms $[8,9]$.

Russell et al, [10] reported that two Pestalotiopsis microspora isolates were uniquely able to grow on polymer polyester polyurethane (PUR) as the sole carbon source under both aerobic and anaerobic conditions. Molecular characterization of this activity suggests that a serine hydrolase is responsible for degradation of PUR. The broad distribution of activity observed and the unprecedented case of anaerobic growth using PUR as the sole carbon source suggest that endophytes are a promising source of biodiversity from which to screen for metabolic properties useful for bioremediation.

Degradation of polymer was confirmed by ligninolytic white rot fungi, Phanerochaete chrysosporium and observed by weight loss, decrease in thickness, decrease in intensity of functional groups like $\mathrm{C}$ (O) $\mathrm{NH}, \mathrm{CO}$ and formation of new functional groups like $\mathrm{COOH}$ and $\mathrm{CHO}$. Also the color of polymer sheets becomes brownish and surface morphology become rough when sheets are exposed to Phanerochaete chrysosporium fungi which shows effect of enzymatic activity on polymer sheets [11]. Fungi play major roles in decomposition, nutrient cycling, plant symbiosis and pathogenesis of bio wastes and thus make it an element of fundamental importance in terrestrial ecosystems. They are also used as a tool for biological control against pests and diseases of plants on the other hand it has the ability to transform toxic metals in the context of bioremediation. Mycelia growth and function can be influenced by simulated environments like homogeneous and heterogeneous conditions [12, 13].

Raaman, et al, [4] Resulted that polythene strips treated with Aspergillus niger and Aspergillus japonicus showed appreciable surface corrosion, folding and cracks under laboratory conditions, due to the fungal extracellular metabolites and fungal enzymes. Polyethylene was studied over a period of 2 and 4 weeks. Biodegradation was measured in terms of mean weight loss, which was nearly 8 to $12 \%$ after a period of 4 weeks. Further, SEM analysis confirmed the degradation revealing the presence of porosity and fragility of the fungal degraded polythene surface. Aspergillus japonicus showed $12 \%$ degradation potential when compared to Aspergillus niger of $8 \%$ degradation in one-month period.

\section{LACCASE ENZYME}

Laccase enzyme has broad substrate specificity towards aromatic compounds containing hydroxyl and amino groups which were considered the main compound forming common commercial plastic. These enzymes were known to catalyze the oxidation of a wide range of phenolic compounds and aromatic amines. Laccase secretion in fungi is influenced by culture conditions such as nature and concentration of carbon and nitrogen sources, media composition, $\mathrm{pH}$, temperature, and the presence of inducers... etc. [14]. Laccases are blue multicopper oxidases, which catalyze the monoelectronic oxidation of a broad spectrum of substrates, for example, ortho- and para-diphenols, polyphenols, aminophenols, and aromatic or aliphatic amines. Hence, they are capable of degrading lignin and are present abundantly in many white-rot fungi. They act on both phenolic and nonphenolic lignin-related compounds as well as highly recalcitrant environmental pollutants, and they can be effectively used in paper and pulp industries, textile industries, xenobiotic degradation, and bioremediation and act as biosensors. Recently, laccase has been applied to nanobiotechnology, which is an increasing research field, and catalyzes electron transfer reactions. $[\mathbf{1 5}, \mathbf{1 6}]$.

Mohammad I. Khalil et al., [14] showed that the Myceliophthora sp. Fungus, capable to produce Laccase enzyme in optimum conditions for the enzyme producing are $\mathrm{pH}(5.0)$ and temperature $30 \mathrm{C}^{\circ}$. The scanning electronmicroscope results showed that the fungi Myceliophthora Sp. Which grow with plastic pieces able to erode the plastics surface in a high percent this due to activity of Laccase enzyme. $\mathrm{pH}$ concentrations were used to find out which is the best $\mathrm{pH}$ level can the fungi secrete 
Laccase enzymes in higher level. Safari et al., [17] recorded that culture $\mathrm{pH}$ is an index of fungi enzyme activity; wherever the $\mathrm{pH}$ was low, fungi activity was high. Incubation temperature to produce Laccase enzymes from the fungus Myceliophthora sp. was 30C. So temperature effect on fungus Laccase productivity. Laccase was the responsible enzyme due to its non-specific oxidative action. Biodegradation of plastic with Myceliophthora sp. Is the greatest so far observed.

\section{Mycomaterial Production}

A few years ago, mushrooms were only considered as an edible vegetable for cooking but now, its derivatives made from agricultural wastes like stalks or seed husks with fungal mycelium which acts as a self-assembling glue can be used for a more noble purpose. Fungus mycelium act as a natural glue, where it latches onto whatever around it which is usually any low value organic matter like plant stalks or cotton hulls to create a super-dense network of threads [18]. The fungi based mushroom packaging material can be considered as an alternative to conventional plastic and are cost competitive to any other standard foams. Polystyrene foam whose main component is derived from petroleum or natural gas is a prominent packaging material. Incorporating mycelium based materials for packaging could help in reduced polystyrene foam consumption, and will eventually lead the way for eco-friendly packaging, without any compromise on cost or performance [19-21]. Mycelium is a fast growing vegetative part of a fungus which is a safe, inert, renewable, natural and green material which grows in a mass of branched fibres, attaching to the medium on which it is growing and can be originated from mainly biological wastes and agricultural wastes. The self-assembling bonds formed by mycelium grows quickly and produces miles of tiny white fibres which envelopes and digest the seed husks, binding them into a strong and biodegradable material. Mycelium based materials have the potential to become the material of choice for a wide variety of applications, with the advantage of low cost of raw materials and disposal of polystyrene posing an environmental issue. [22, 23]. As the mycelium grows, a network of branching hyphae, primarily composed of chitin, binds together the nutritive substrate consisting of biomass and creates a vast three-dimensional matrix. Biofoams offer several additional advantages over polymeric foams, including low cost of production, fast renewability, and carbon capture and storage, and can serve as replacements for the petroleum-based polymeric materials for applications in insulation, lightweight fill, packaging, noise control, and sandwich panels $[\mathbf{1 , 2 4}$ ]. The mycelium (mushroom roots) can be grown in a mold to form different shapes for different items and they grow quickly into a dense material. Once reaching the desired density and shape, the material is dehydrated, to stop further growth. After its useful life as a packaging material, mycelium based materials can be left out in your backyard and it decomposes within a few weeks. The material is much cheaper when made on a grand scale and is a lot easier to biodegrade than recycling $[25,26]$.

\section{MYCELIUM-BASED FOAMS}

Increasing attention has been paid to mycelium-based biocomposites as alternative materials to synthetic packaging and insulation panels, as well as developing a new-concept bio-inspired design. Since this is still a pioneering field. Reducing the use of non-renewable resources is a key strategy of a circular economy. Mycelium-based foams and sandwich composites are an emerging category of biocomposites depending on lignocellulosic wastes and the natural growth of the living fungal organism. While growing, the fungus cements the substrate. The final product can be shaped to produce packaging materials, bricks or new-design objects. Only a few pioneer companies in the world retain a significant know-how, as well as the ability to provide the material characterization [27-29]. Yang et al., [1] reported that fungal mycelium-based biofoam is relatively lighter weight than water, soils, or most other materials used in the civil engineering industry, the dried biofoam 
demonstrates good thermal conductivity, this biofoam exhibits fairly good elastic moduli when it is dried, this biofoam exhibits strong elastic anisotropy, this biofoam has met or exceeded like characteristics of the conventional polymeric thermal foams except dry density.

\section{CONClusion}

This review demonstrates that microorganisms especially fungi are capable of degrading most of the organic and inorganic materials. Fungal mycelium-based biofoam offers great potential for application as an alternative insulation material for building and infrastructure construction, or an alternative lightweight backfill material for geoengineering and other.

\section{REFERENCES}

[1] Yang Z, Zhang F, Still B, White M, Amstislavski P. Physical and mechanical properties of fungal mycelium-based biofoam. Journal of Materials in Civil Engineering. 2017; 29(7): 04017030.

[2] Shimao M. Biodegradation of plastics. Curr. Opin. Biotechnology. 2001; 12: 242-247.

[3] Madigan MT, Martinko JM, Parker J. Biology of Microorganisms, 10thed. Prentic Hall, Upper Saddel River, NJ. 2003; 676- 679.

[4] Raaman N, Rajitha N, Jayshree A, Jegadeesh R. Biodegradation of plastic by Aspergillus spp. isolated from polythene polluted sites around Chennai, J. Acad. Indus. Res., 2012; 1(6): 313-316.

[5] Das MP, Kumar S. Microbial deterioration of low density polyethylene by Aspergillus and Fusarium sp. Int J. Chem. Tech. Res. 2014; 6(1): 299-305.

[6] Munir E, Harefa R, Priyani N, Suryanto D. Plastic degrading fungi Trichoderma viride and Aspergillus nomius isolated from local landfill soil in Medan. In IOP Conference Series: Earth and Environmental Science. 2018; 126(1): 012145. IOP Publishing.

[7] Ma A, Quentin W. Identification of esterase in Aspergillus flavus during degradation of polyester polyurethane." Journal of Student Science and Technology. 2013; 6. 2.

[8] Loredo-Treviño A, García G, Velasco-Téllez A, Rodríguez-Herrera R. Cristóbal N. Polyurethane foam as substrate for fungal strains, Advances in Bioscience and Biotechnology. 2011; 2: 52-58.

[9] Khan S, Nadir S, Shah ZU, Shah AA, Karunarathna SC, Xu J, Hasan F. Biodegradation of polyester polyurethane by Aspergillus tubingensis. Environmental Pollution. 2017; 225: 469-480.

[10] Russell J, Huang J, Anand P, Kucera K, Sandoval A, Dantzler K, Hickman D, Jee J, Kimovec F, Koppstein D, Marks D, Mittermiller P, Nu'ñez S, Santiago M, Townes M, Vishnevetsky M, Williams N, Vargas M, Boulanger L, Bascom-Slack C, Strobel SA. Biodegradation of Polyester Polyurethane by Endophytic Fungi, applied and environmental microbiology. 2011; 6076-6084.

[11] Chonde S, Chonde S, Bhosale P, Raut P. Studies on degradation of synthetic polymer nylon 6 by lignolytic fungus Phanerochaete chrysosporium NCIM 1073, Journal of Environmental Research And Development. 2012; 6(3A): 709-714.

[12] Boswell GP, Jacobs H, Davidson FA, Gadd GM, Ritz K. Growth and function of fungal mycelia in heterogeneous environments. Bulletin of Mathematical Biology. 2003; 65(3): 447.

[13] Boswell GP, Jacobs H, Ritz K, Gadd GM, Davidson FA. The development of fungal networks in complex environments. Bulletin of Mathematical Biology. 2007; 69(2): 605.

[14] Mohammad IK, Nadeem AR, Riyadh KA. Biodegradation of Polymers by Fungi Isolated from Plastic Garbage and the Optimum Condition Assessment of Growth, Journal Raf. Env., 2013; 1(1): 33-43.

[15] Viswanath B, Rajesh B, Janardhan A, Kumar A, Narasimha G. Fungal Laccases and Their Applications in Bioremediation, Enzyme Research. 2014; 1-21. 
[16] Kumar VV, Kirupha SD, Periyaraman P, Sivanesan S. Screening and induction of laccase activity in fungal species and its application in dye decolorization. African Journal of Microbiology Research. 2011; 5(11): 1261-1267.

[17] Safari S, Emtiazi G, Hajrasuliha S, Shariatmadari H. Biodegradation of some agriculture residues by fungi in agitated submerged cultures. African J. Biotechnology. 2005; 4(10): 1688-1061.

[18] Miles PG, Chang ST. Mushrooms: cultivation, nutritional value, medicinal effect, and environmental impact. CRC press. 2004; 159-185.

[19] Ashok A, Rejeesh CR, Renjith R. Biodegradable polymers for sustainable packaging applications: a review. IJBB, 1(11). 2016.

[20] Farmer N. (Ed.). Trends in packaging of food, beverages and other fast-moving consumer goods (FMCG): markets, materials and technologies. Elsevier. 2013.

[21] Arifin YH, Yusuf Y. Mycelium fibers as new resource for environmental sustainability. Procedia Engineering. 2013; 53: 504-508.

[22] Lelivelt RJ, Lindner G, Teuffel PM, Lamers H, SD US. The mechanical possibilities of mycelium materials. Eindhoven University of Technology, Eindhoven, Netherlands. 2015.

[23] Abhijith R, Ashok A, Rejeesh CR. Sustainable packaging applications from mycelium to substitute polystyrene: a review. Materials Today: Proceedings. 2018; 5(1): 2139-2145.

[24] Travaglini S, Dharan C, Ross PG. Mycology matrix sandwich composites flexural characterization. In Proceedings of the American Society for Composites. 2014; 8-10.

[25] Stamets P. Mycelium running: how mushrooms can help save the world. Random House Digital, Inc.. 2005.

[26] Schiffman R. Packing materials grown from mushrooms. New Scientist, 2013; 218(2921): 29.

[27] Girometta C, Picco AM, Baiguera RM, Dondi D, Babbini, S., Cartabia, M., Savino, E. Physico-mechanical and thermodynamic properties of mycelium-based biocomposites: a review. Sustainability. 2019; 11(1): 281.

[28] Santhosh BS, Bhavana DR, Rakesh MG. Mycelium composites: An emerging green building material. Int. Res. J. Eng. Technol. 2018; 5: 3066-3068.

[29] Arifin Y, Yusuf Y. Mycelium fibers as new resource for environmental sustainability. Procedia Eng. 2013; 53: 504-508

Citation: Waill A. Elkhateeb \& Ghoson M. Daba (2019). The Amazing Potential of Fungi in Human Life. ARC Journal of Pharmaceutical Sciences (AJPS), 5(3), pp.12-16. DOI: http://dx.doi.org/10.20431 /2455-1538.0503003

Copyright: (C) 2019 Authors. This is an open-access article distributed under the terms of the Creative Commons Attribution License, which permits unrestricted use, distribution, and reproduction in any medium, provided the original author and source are credited. 